\title{
FUTURE OF OFFLINE MARKETING AHEAD OF THE RAPID DEVELOPMENT OF ONLINE MARKETING
}

\author{
Olena Bobalo' \\ Lviv Polytechnic National University, Ukraine
}

\begin{abstract}
Quick internet coverage all over the world created new possibilities of its usage as a new mass media which are more flexible, dynamic and, what is more important, almost uncontrollable. And they require approaches and knowledges which differ from existing ones. So companies, which want to be active in the biggest net and want to influence on theirs target audiences, they started to develop direction of internet (on-line) marketing. New marketing activities created new professions directly connected to internet. In recent years on-line marketing became very important part of marketers' life and very fashionable. Every company which understands the importance of new technologies actively lives in the internet. Its marketing activity is more and more concentrated on internet. So, main aim of this article is to investigate the company's real possibilities to catch Ukrainian target audience through the internet. So, the next tasks were set to achieve purpose given above: to analyze internet penetration in Ukraine and compare it with other countries, to separate the types of target audience who uses internet on the regular base, to investigate the presence of people with high purchasing power in the internet and determine their activity in the net. The research's methodology of this paper is based on comparative analysis - for observation of internet penetration in different countries; scientific cognition - for analysis of social groups in internet; system-activity principle as a part of system principles - when a part of internet users is separated according to their activity and income level; specific-scientific methodology-for formalization of utilization of offline marketing tools; scientific abstraction - for the conclusions. Some research results are based on demographic statistics; results of periodic investigation of internet users' profile. Results of the research show that big amount of potential consumers with highest purchasing power aren't regular internet users. That is why the offline marketing practices need to be observed as a substitute of online marketing. And significant part of the paper is dedicated to find out which offline marketing instruments are still useful for Ukrainian consumers. Real examples of offline marketing are giv-en, including experience of well-known Ukrainian IT-companies who are leaders of modern technologies implementations. Analysis of most common offline marketing techniques shows that even progressive companies of information and communication technology sector often use such instruments.
\end{abstract}

Key words: offline marketing, internet market, internet users, highest purchasing power buyers, offline marketing techniques Ukraine.

JEL Classification: M31, L86

\section{Introduction}

Online marketing becomes more and more popular among marketers every year. Quantity of vacancies connected to internet marketing grows constantly. Representatives of Human Recourses' Departments are looking for SMM/SEM/SEO/PPC employees, internet socialmedialisteners, specialistsine-mail campaigns, digital marketing etc. Marketing departments start to refocus from classical marketing approaches and instruments into online marketing. That is understandable: information and computing changes on the global markets lead to falling of the consumer's interest to traditional information sources. Marketing specialists try to find something new to attract targets audiences and tie them up to company's products. Now new generation choose not Pepsi, but internet. A lot of young generation of marketing executives stops to work with classical marketing instruments and totally switched to online marketing. All of them are trying to catch their target audience in the internet. Ukrainians companies aren't standing apart of such processes and acts very vigorously in searching of online experts. As of March 1,2018 , one of the most sought-after online job search site hh.ua ranked online marketing vacancies on the 3 rd place between 31 specialist's fields of marketing vacancies (Head Hunter, 2018). So here is the list of questions: still offline marketing alive? Does it valid in modern digital

\footnotetext{
Corresponding author:

${ }^{1}$ Department of Marketing and Innovatics; Department of Social Communications \& Information Activity,

Lviv Polytechnic National University.

E-mail: olena.y.bobalo@lpnu.ua
} 
life? Does it have a future? Could we catch all kinds of target audience in internet?

For this moment there are no complicated researches on the given theme which analyze valid situation in Ukraine, so author decided to investigate questions mentioned above. For this purpose, studies of Ukrainian and international research agencies were used. Among them are Presentation of the study's results of the Ukrainian Internet user behavior by Google Connected Consumer Study, Internet Penetration in Ukraine by Factum Group Ukraine, Age structure of the population of Ukraine by State Statistics Service of Ukraine. All of them were fulfilled during 2017. Also author's personal investigations during second part of 2017 are included into research. They are based on sources of professional internet marketing and scientific sources such as Trust in Digital Technology Will Be the Internet's Next Frontier, for 2018 and Beyond by Scientific American, 5 clever offline marketing strategies for $\mathrm{B} 2 \mathrm{~B}$ brands by $\mathrm{b} 2 \mathrm{bmarketing.net,}$ 6 Offline Marketing Strategies that Support Your Online Brand by Hinge and analyze of ICT companies' visual

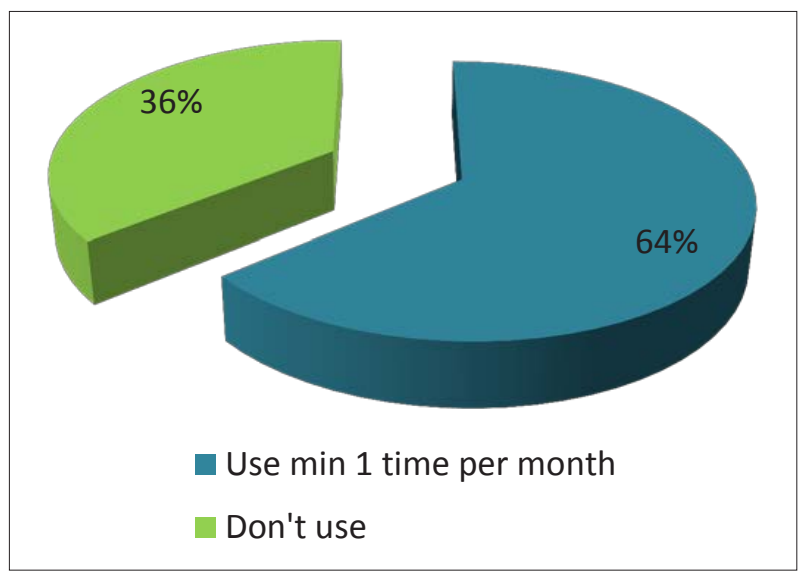

Graph 1. Internet users in Ukraine

Source: Factum Group, 2017 and activity presence during IT Arena Lviv (biggest IT event in Eastern Europe).

\section{Conducting research and results}

In July-August 2017, Factum Group Ukraine conducted the observation of internet market in Ukraine. Results say that 64\% (21 million persons) of Ukrainians use internet. It is shown on the graph 1.

It means that $36 \%$ don't use it at all and it's more than 11.7 million of Ukrainians. It's necessary to take into account that $64 \%$ includes persons who use internet at least 1 time per month. Could such kind of persons be effective computer/internet users? There is a doubt.

According Google survey (Google Connected Consumer Study, 2017) 66\% of Ukrainians use internet, but only $48 \%$ of them use internet daily. This is approximately 16 million persons.

It's necessary to say that Ukraine has lower internet penetration even than our closest neighbors. Graph 2 indicates that internet penetration in Ukraine is only $46 \%$, which is by $6 \%$ less than in Russia, by $16 \%$ less than in Poland.

Given on the graph 3, internet age structure shows that most active internet users are between 15 and 44 years old $-71 \%: 35 \%$ of the age $15-29$ and $36 \%$ of the age $30-44$.

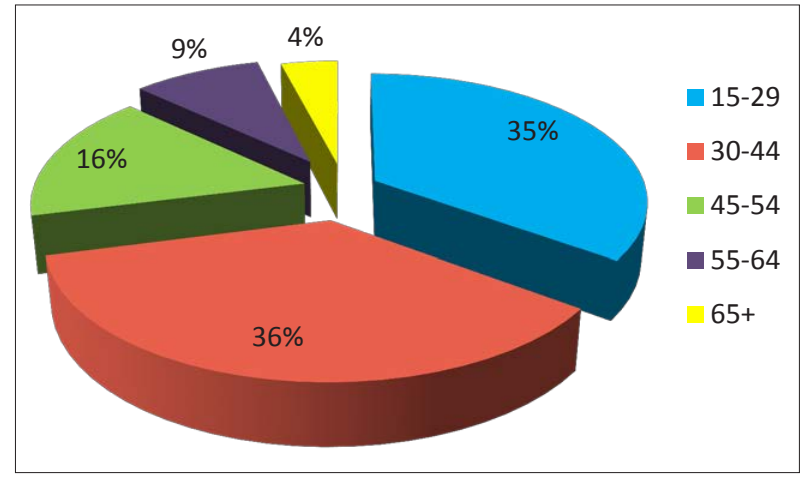

Graph 3. Age structure of the internet users in Ukraine Source: Factum Group, 2017

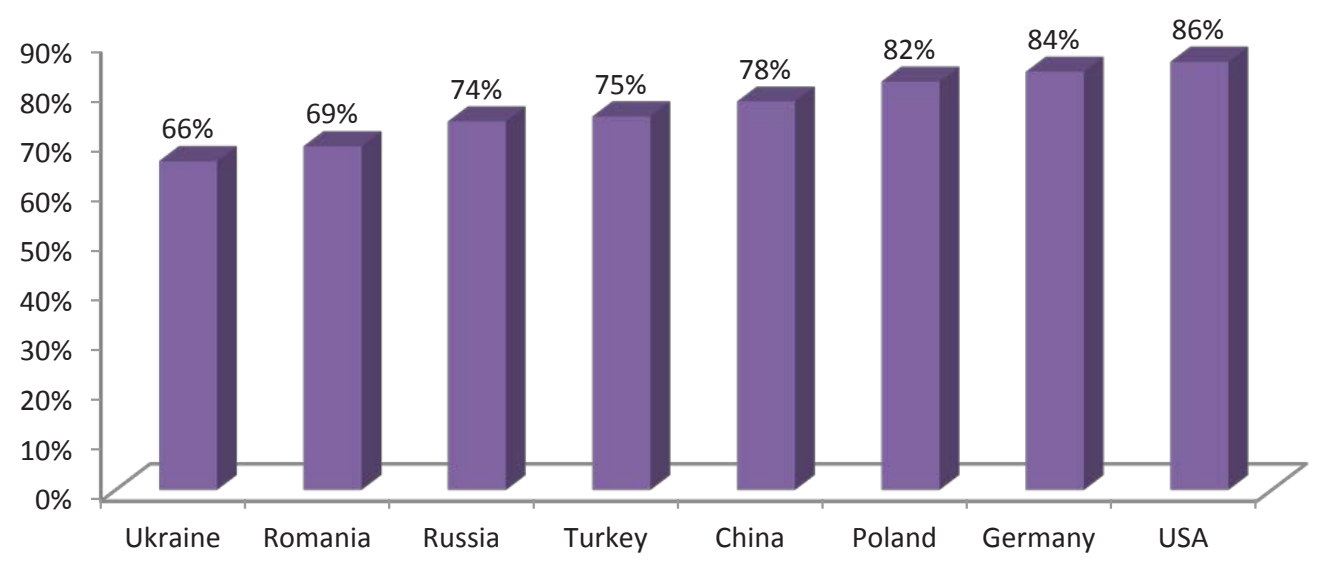

Graph 2. Internet penetration in different countries

Source: Google, 2017 
Persons from the gap 35-65 years old belong to the highest purchasing power buyers of the Ukrainian population. As this survey doesn't show the necessary results, it's better to observe Google Connected Consumer Study 2017. Graph 4 shows a more detailed distribution by age categories.

So, near 51\% internet users belong to consumers with the highest purchasing power. Quantitatively it's 8.16 million persons.

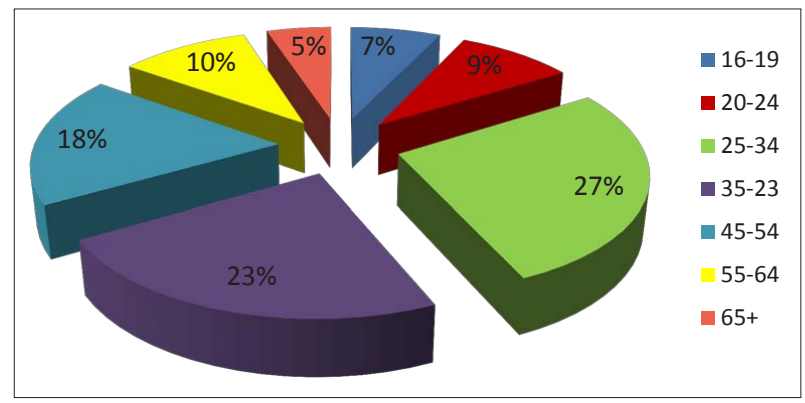

Graph 4. Age structure of the internet users in Ukraine

Source: Google, 2017

According to the survey of State Statistics Service of Ukraine, in 2017 population 35-65 years old counts 18.4 million Ukrainians (State Statistics Service of Ukraine, 2017). Taking into account that active online users of that age consist of 8.2 million persons, so, biggest part of the most accounts' payable population doesn't use internet in their quotidian life: approximately 10.2 million Ukrainians which is shown on the graph 5.

This data are confirmed by the graph 6 and 7 . Where is shown that more than $50 \%$ of internet user are students, pupils, unemployed, employees without high education, retired or engaged in the house hold. And these groups in

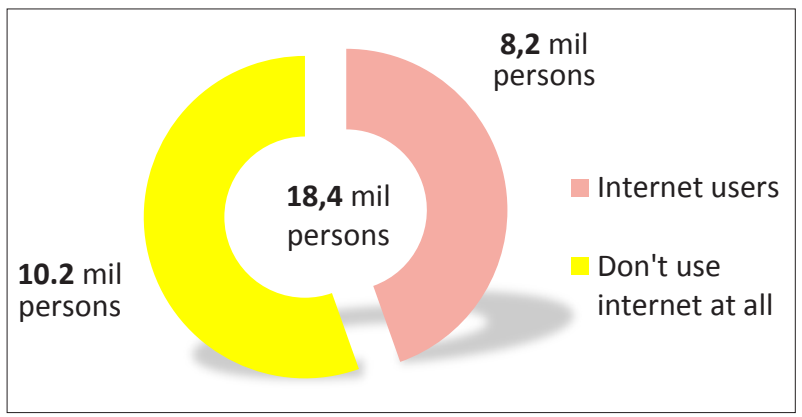

Graph 5. Internet usage by the most accounts payable consumers

Source: State Statistics Service of Ukraine

Ukraine belong to categories with rather low or average incomes. And only 27\% of persons from graph 6 could belong to persons with high and below average incomes.

It's necessary to take into account that quantity of internet users increases almost due to the youngest category which has a low level of buying possibilities. But if to assume that Ukraine will develop like developed countries, where marriage and purchase of residential real estate are postponed to more matured ages, then age gap 25-34 years old (27\%) becomes very attractive.

Counting on the written above we could make a conclusion that it's impossible to catch biggest part of the most accounts' payable audience through the internet, so producers of goods or services, which are focused on 35-65 years old consumers, should use more traditional marketing tools or invent something extra new. Experienced executive Elizabeth Harr, co-founded a Microsoft solutions provider company, recommends some offline marketing strategies that can support online brands: networking, speaking engagements, print

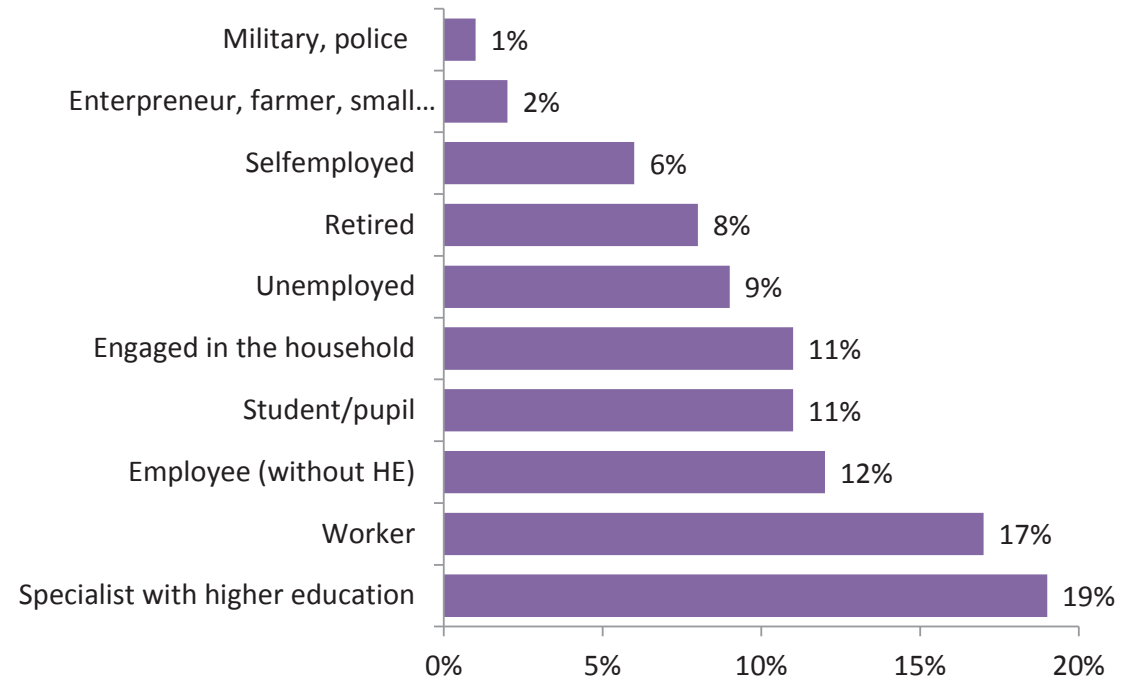

Graph 6. Social structure of regular Ukrainian internet users, \%

Source: Factum Group, 2017 


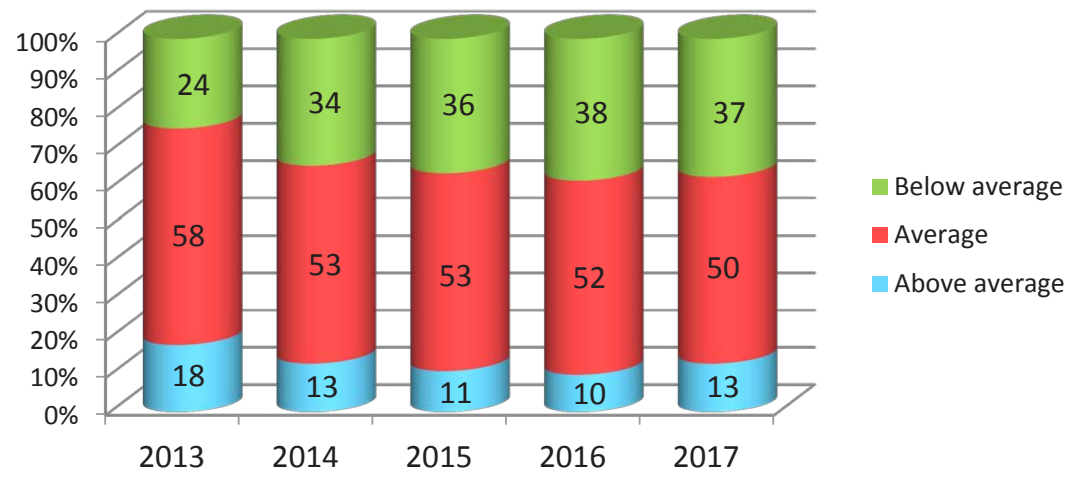

Graph 7. Income level of regular Ukrainian internet users, \%

Source: Factum Group, 2017

publications, cold calls, print advertising, associations and trade shows (Haar, 2017).

Also, counting on Ukrainian consumer's psychology, possibility to receive fake but not original product, a list of products and services which aren't good for selling them through the internet, especially in Ukraine, is recommend:

- Elite products from the common categories (expensive): automobiles, interior's elements, alcohol, jewelry, consumer electronics, home appliance, smokings/evening dresses;

- Services which are buying by the recommendation: architecture \& interior's design, SPA-procedures, sport clubs etc.;

\section{- Professional and production equipment.}

In these cases personal contact is needed and customer wants to see the product personally. Such products and services could be (and better be) promoted through internet mostly with informational aim. Counting on the growing quantity of bots, main aim of which is to promote client's goods/services/ image and to discredit the other for what they are also payed, the trust to comments started to decrease during last few years (Chakravorti, 2018). Also quantity and quality of advertising block programs increases year by year, in 2016 PageFair registered 30\% growth of global advertising block programs use (admitad, 2017) and biggest social network Facebook announced that they are reducing posts from brands, publishers, marketers, and news stories (The Telegraph, 2018). All that will lead to diminution of advertising possibilities in internet.

Analysis of the different marketing instruments' utilization by the big amount of Ukrainian's companies (including big ITC companies) lets propose the list of offline marketing techniques which seems to be useful for a long time:

- analytics;

- visual identity/brand book;

- promotions, event marketing;

- personal contacts;
- internal communications;

- ATL.

If secondary analytics/surveys could be found in the internet, serious primary surveys mostly still fulfill by the personal interviews:

- Target audience, it's behavior, influence categories;

- Products/services;

- Company;

- Results of the off/online actions;

- Information for the company/marketing strategy's creation;

- Both kinds of environment: internal \& external (incl. competitors, distribution etc.);

- Loyalty/acknowledgment/popularity;

- Focus groups, panels, trials.

It doesn't mean that such kind of analytics is impossible to fulfill through internet, but in most of the cases it's easier to receive offline results and they will be more trustable.

With the help of internet is possible to investigate company's site activities and to run some analytics with Loyalty Clubs.

Visual identity is always topical even if the company exists only in the virtual world and the main tools are:

- Company's name / TM, its logo, slogan etc.;

- Architectural constructions/interior;

- Institutional/public documents (forms, presentations);

- Business cards;

- Souvenir products;

- Press-walls, etc.

Logo, font, slogan, set of colors, requirements to logo placement (and other parts of brand book) help to separate any company/product from another. Google, Apple, Microsoft spend huge amounts of money to create individual, interesting and impressive buildings and interiors not only to attract best employees but to amaze visitors, which is shown at the figure 1 . This positively influences on company's image (McDermott, 2017) (figure 1).

During visits of IT-companies or any exhibition (even high-tech or IT), products with company's visual identity always are present. Pens, souvenirs, flash 

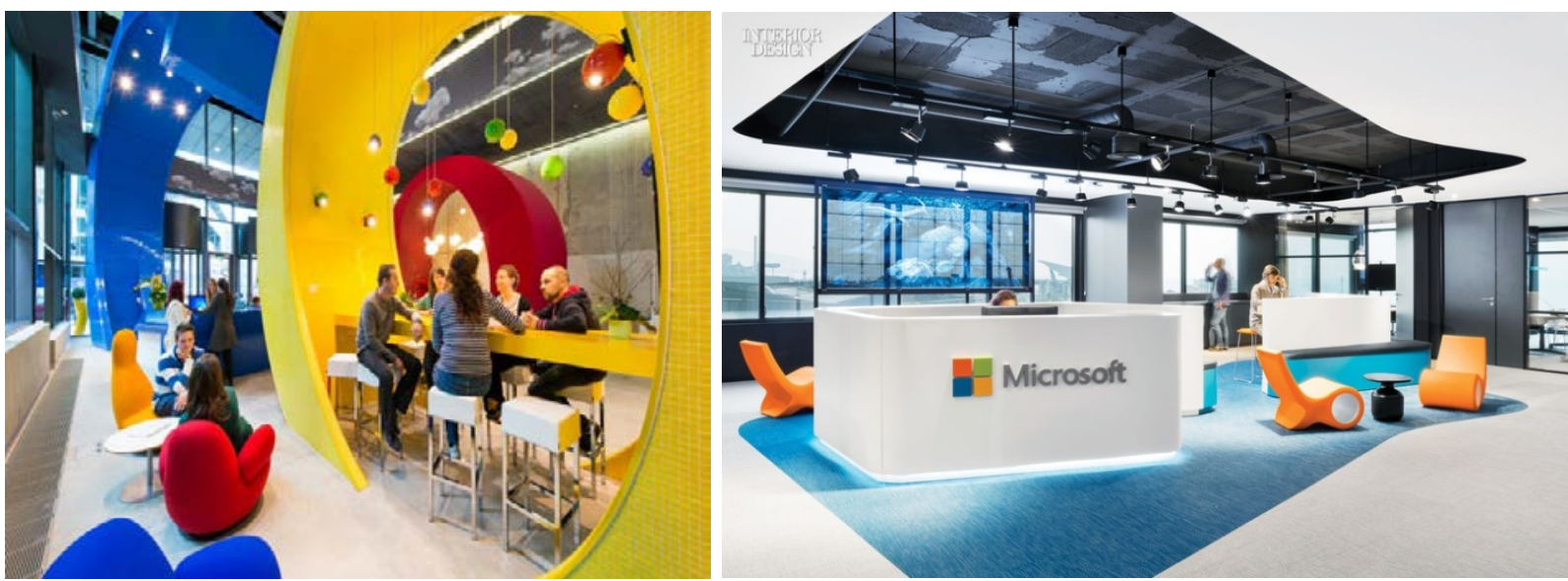

Figure 1. Google and Microsoft offices

Source: Setia, 2017; McWhirter, 2016

drives, t-shirts, bags etc. - all of these goods are with company's/products logos: look at the figure 2.

Offline promotions and event marketing continue to be important part of marketing strategies (Haar, 2017; McDermott, 2017) and the most often used techniques are: - Participation in exhibitions, trade shows, salons and industry events;

- Sponsorships / patronage;

- Press conferences;

- Social and promotional events.

All these tools lead to quick results and are frequently used by well-known Ukrainian and international companies and organizations. Figure 3 shows stand of IT-company eleks during IT Arena Lviv, press conference IT-companies Softserve, Epam, international company Bayer and Klichko foundation. Promos feed target audience in terms of speaking engagement, network creation and face-to-face connections. They could help to position company as a high professional, customer friendly, society oriented and opened to consumer institution. Such promotional events as trials and testing (especially for FMCG and other commodity goods) are difficult to fulfill through online marketing. It's possible to send samples by post mail, but in such case activity lose its main goal: to stimulate consumer to make immediate purchase.
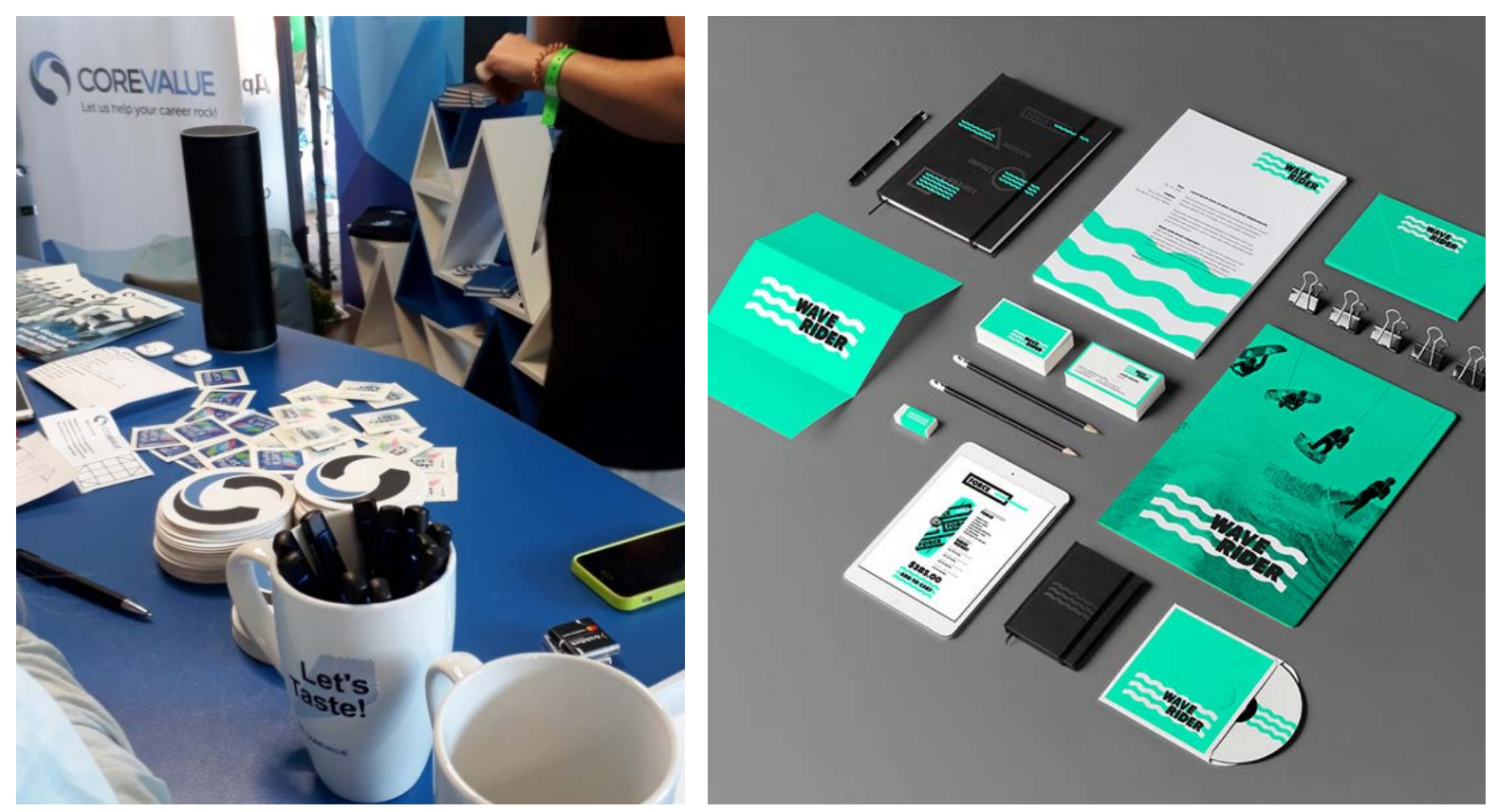

Figure 2. Items with clear brand identity

Source: own photo and from internet 

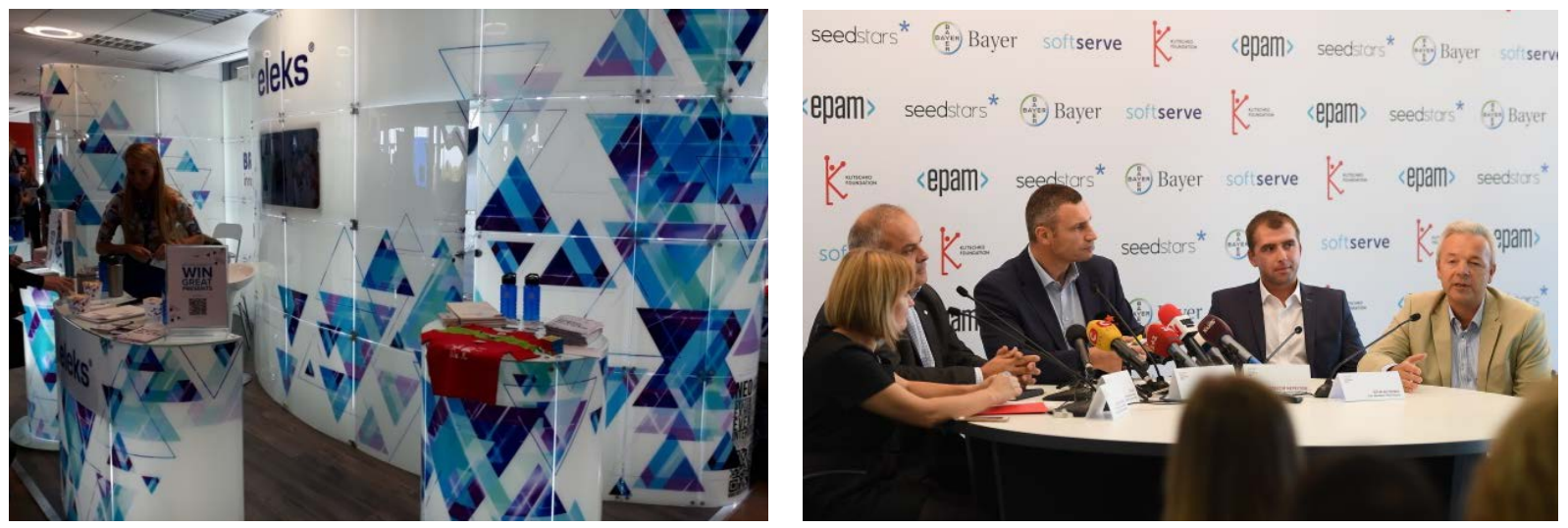

Figure 3. Examples of offline promos

Source: own photo and from internet

For example famous tech-companies like Apple, Yahoo, Alphabet, Seagate, HP are active sponsors of Super Bowl and other sport activities (Mayo, 2016; Connelly, 2017).

As it was mention above personal contacts are frequently used for achieving positive results of external institutional communications. So such kinds of instruments are still useful in the digital age:

- Official/unofficial meeting (banks, industrial equipment, education and repair services, merchandising, consulting etc.);

- Phone calls (service centers, loyalty programs, selling through the internet and TV shops, cold calls, etc.);

- Doors open days;

- Work with key clients.

Leading world universities continue to invite potential students to visit their campuses to get acquainted with all the benefits of student life. They propose free of charge campus excursions and meetings with teaching staff and students.

Tesla now is successfully selling its vehicles only through internet, but what will happen when there will be 100-1000 of such proposals from other producers? It's logical to assume that such companies will come back to proven personal contacts and test drives to persuade clients in buying their product, but not competitors.

For a long time personnel of each company plays an important role of ambassador between institution and target audience. When internal company`s image is equal to external, such companies are successful. This equity could be reached due to internal communications. And some of them are more effective being offline:

- Solemn / corporate events;

- Personnel training;

- Contests / lottery / loyalty programs for employees;

- Signboards / boards / working tools.

A lot of prominent institutions continue to hold the internal events offline. Maserati solemn events, Nestle team building programs, New Year celebrations in or outsidethe office, ChristmasBallsin Austrianinstitutionsit's a short list of actual internal offline events.

Graph 8 shows that $49 \%$ of Ukrainians trust Ukrainian $\mathrm{TV}$ as a source of information, so confidence level to media is quite high (Sociological Group «Rating», 2018). That is why ATL activities are still popular between different kinds of companies. TV, press, radio and outdoor advertising remains the most expensive type of marketing tools.

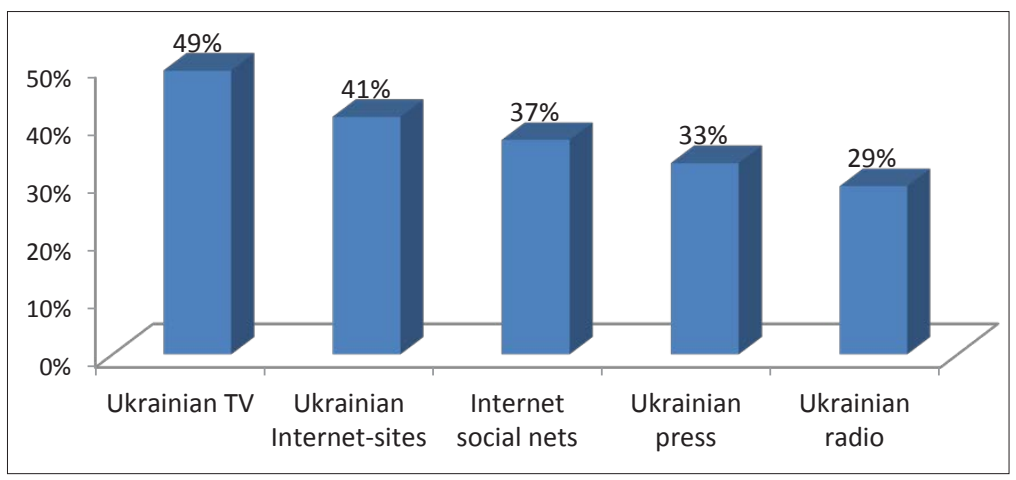

Graph 8. Ukrainians' trust level to different media

Source: Sociological Group «Rating», 2018 


\section{Conclusions}

So, information mentioned above leads us to some conclusions and recommendations:

1. It's impossible to catch biggest part of the audience with the highest purchasing power through the internet, 'cos this target audience don't use internet at all or use it occasionally.

2. Some products and services aren't good for selling them through the internet.
3. Offline marketing is still effective tool and so will stay in the nearest future.

4. Combination of on-line and offline marketing is efficient and could give synergetic effect, so marketing strategies should include both of them.

5. Due to the growth of information flows, it is necessary to look for new ways of influencing the consumer, as internet users becomes more advanced and increase of quantity and quality of advertising block programs, installation of which increases each year.

\section{References:}

Admitad (2017, August). Adblock vs. Cost-Per-Action marketing: cooperation works better than conflict partnership. Search Engine Land. Retrieved from: https://searchengineland.com/adblock-vs-cost-per-actionmarketing-cooperation-works-better-conflict-279811

Chakravorti B. (2018, January). Trust in Digital Technology Will Be the Internet's Next Frontier, for 2018 and Beyond. Scientific American. Retrieved from: https://www.scientificamerican.com/article/trust-in-digitaltechnology-will-be-the-internet-rsquo-s-next-frontier-for-2018-and-beyond/

Connelly T. (2017, January). Apple moves into sports sponsorship with FC Bayern Munich partnership. The Drum. Retrieved from: http://www.thedrum.com/news/2017/01/31 /apple-moves-sports-sponsorshipwith-fc-bayern-munich-partnership

Factum Group (2017, December). Proniknovenie Interneta v Ukraine. Ukrainian Internet Association. Retrieved from: http://inau.ua/sites/default/files/file/1801/iv_kvartal_2017.pdf

Google (2017). Presentation of the study's results of the Ukrainian Internet user behavior. Google Connected Consumer Study. Retrieved from: https://ukraine.googleblog.com/2017/10/google-connected-consumerstudy-2017.html

Haar E. (2017, July). 6 Offline Marketing Strategies that Support Your Online Brand. Hinge. Retrieved from: https://hingemarketing.com/blog/story/7-offline-marketing-strategies-that-support-your-online-brand

Head Hunter (2018, March). Retrieved April 3, 2018, from: https://hh.ua/search/vacancy?enable snippets $=$ true \&specialization $=3 \&$ currency_code $=U A H \&$ clusters $=$ true $\&$ area $=5 \&$ from $=$ cluster_area

Mayo B. (2016). Apple sponsoring Super Bowl host committee with free prod-ucts and equipment but declined to be included in marketing. 9to5. Retrieved from: https://9to5mac.com/2016/01/19/apple-sponsoring-superbowl-host-committee-with-free-products-and-equipment-but-declined-to-be-included-in-marketing/

McDermott M. (2017, October). 5 clever offline marketing strategies for B2B brands. B2B Marketing. Retrieved from: https://www.b2bmarketing.net/en-gb/resources/blog/5-clever-offline-marketing-strategies-b2b-brands

McWhirter G. (2016). 4 Tech and Finance Companies Rock Out at the Office. Interior Design. Retrieved from: http://www.interiordesign.net/slideshows/detail/8946-work-this-way-4-tech-finance-offices/3/

Setia R. (2017). 20 Trickiest Questions Asked in Google Interview. Tech Blog Corner. Retrieved from: http://techblogcorner.com/2017/11/24/trickiest-questions-asked-in-google-interview/

Sociological Group «Rating» (Rating Group Ukraine) (2018, January). Otsinka Medychnoi Sfery v Ukraini: gruden' 2017. Retrieved from: http://ratinggroup.ua/research/ukraine/ocenka_medicinskoy_sfery_v_ukraine_ dekabr_2017.html

State Statistics Service of Ukraine (2017). Vikova Struktura Naselennya Ukrainy (1989-2017). Retrieved from: http://www.lv.ukrstat.gov.ua/dem/piramid/all.php

The Telegraph (2018, January). Facebook overhauls News Feed to promote 'more meaningful' posts from family and friends - raising questions for businesses. Retrieved from: http://www.telegraph.co.uk/technology/2018/01/12/ facebook-overhauls-news-feed-promote-meaningful-posts 